\title{
Interlinking climate change with water- energy-food nexus and related ecosystem processes in California case studies
}

\author{
Qinqin Liu
}

\begin{abstract}
Global climate change creates critical challenges with increasing temperature, reducing snowpack, and changing precipitation for water, energy, and food, as well as ecosystem processes at regional scales. Ecosystem services provide life support, goods, and natural resources from water, energy, and food, as well as the environments. There are knowledge gaps from the lack of conceptual framework and practices to interlink major climate change drivers of water resources with water-energy-food nexus and related ecosystem processes. This paper provided an overview of research background, developed a conceptual framework to bridge these knowledge gaps, summarized California case studies for practices in cross sector ecosystem services, and identified future research needs. In this conceptual framework, climate change drivers of changing temperature, snowpack, and precipitation are interlinked with life cycles in water, energy, food, and related key elements in ecosystem processes. Case studies in California indicated climate change affected variation in increasing temperature and changing hydrology at the regional scales. A large variation in average energy intensity values was also estimated from ground water and federal, state, and local water supplies both within each hydrological region and among the ten hydrological regions in California. The increased regional temperature, changes in snowpack and precipitation, and increased water stresses from drought can reduce ecosystem services and affect the water and energy nexus and agricultural food production, as well as fish and wildlife habitats in the Sacramento-San Joaquin Delta (Delta) and Central Valley watersheds. Regional decisions and practices in integrated management of water, energy, food, and related ecosystem processes are essential to adapt and mitigate global climate change impacts at the regional scales. Science and policy support for interdisciplinary research are critical to develop the database and tools for comprehensive analysis to fill knowledge gaps and address ecosystem service complexity, the related natural resource investment, and integrated planning needs.
\end{abstract}

Keywords: Ecosystem services, Ecosystem, Climate change, Water, Energy, Food and environments, Agricultural practices, Ecosystem processes, Sustainable natural resource, Integrated resource management, California, Interdisciplinary research

\section{Review}

\section{Introduction}

Ecosystems provide services for life support, goods, and natural resources from water, energy, food, and the environments. Climate change affects ecosystems' sustainability and causes increased pressure on these ecosystem services. Climate change projections include warmer air temperatures, diminishing snowpack, precipitation

Correspondence: Qliu@water.ca.gov

Department of Water Resources, Natural Resources Agency, Sacramento, CA, USA

uncertainty, increased evaporation, prolonged droughts, and sea level rise (IPCC Climate Change Synthesis Report 2014). For example, climate change effects on water and energy as well as the environments have been evaluated in California (The Third Assessment of California Climate Change Report 2012; California Water Plan 2013; DWR 2015), including the following:

- Projected temperature increasing ranging from 4 to $9{ }^{\circ}$ Fahrenheit $\left({ }^{\circ} \mathrm{F}\right)$ by the year 2100 
- Loss of snowpack with 48-65 \% of snow water content loss by the end of this century

- Droughts with more dry years and less water, which affects food and energy as well as the environments

- More frequent flooding and fire, affecting water quality in watershed

- Rising sea levels

- Increasing energy demand

- Changes in species and habitats

This paper will focus on the climate change drivers of temperature, snowpack, and precipitation interacting with water, energy, food, and related ecosystem processes using California case studies.

Climate change has significant effects on ecosystem processes related to species and environment quality, including habitat loss and species extinctions that are leading to a global loss of biodiversity. Research models predict many species living in the current climate will disappear from 10 to $48 \%$ of Earth's surface by the year 2100 , as a consequence of the planet having developed climates that no living species has ever experienced (Williams et al. 2007). Human population growth has been linked with energy needs that have serial impacts to global climate disruption, habitat loss, and species extinctions (Barnosky et al. 2013). However, it is not clear what are linkages and pathways of major climate change drivers of temperature, snowpack, and precipitation with water, energy, food, and related key ecosystem processes for these habitat loss and species extinctions.

Researches interlinking climate change with waterenergy-food nexus as well as related ecosystem processes is still in an early stage. Case studies have been conducted in the Asia-Pacific Coastal Region to address questions on the environmental security of the waterenergy-food nexus, an important global environmental issue (Taniguchi et al. 2013). Other studies have explored factors that will affect the global food system in the future, including climate change and competition for water, energy, and land (Godfray et al. 2010). Challenges in food, water, and energy sectors are interwoven in complex ways in watersheds, and the regional integration between upstream and downstream of watershed ecosystems is critical in food, water, and energy security (Rasul 2014). Limited assessment with integrated studies of climate change, water, energy, and land included water for land uses as well as water and energy related to climate change (Skaggs et al. 2012; US Department of Energy 2014). A recent study has indicated climate change impacts sustainable livelihoods and ecosystem sustainability related to food, energy, and water for resilient environments and societies (Biggs et al. 2015). An integrated nexus-livelihoods framework and holistic approach were developed to address the interrelated dynamics for the water-energy-food nexus and environmental sustainability. Climate change is one of the influencing factors in this framework with a livelihood perspective, but no clear linkages or pathways have been defined on how climate change influences the waterenergy-food nexus and ecosystem processes in this framework. Other research efforts have begun to explore common challenges in the context of the water-foodenergy-climate nexus (World Economic Forum 2011). Most recent case studies in California have indicated a complex water-energy-food nexus with climate change implications at a regional scale (Liu 2016), and related research began to connect dots with climate change, water, energy, and food related to ecosystems in California (Liu 2014). This research has provided the benefits of public outreach and education (Jablonski, et al. 2015) but still lacks framework and pathways for the key connecting points.

All of this background research and studies have not clearly identified major climate change drivers of temperature, snowpack, and precipitation and how their linkages and pathways connect with life cycles in water, energy, food, and related key elements in ecosystem processes. Lack of knowledge and practices in this research area will limit ecosystem services for integrated natural resources management, sustainable infrastructure investment, and system planning to mitigate and adapt to climate change without compromised ecosystem function. This paper provides research overview, conceptual framework with linkages and pathways to bridge these knowledge gaps, and addresses global climate change challenges in the water-energy-food nexus related to ecosystem processes and practices at a regional scale. Case studies in California were summarized for practices in cross sector ecosystem services and how climate change can affect the water and energy nexus and agricultural food production, as well as fish and wildlife habitats at a regional scale. The objectives of this paper include the following:

1) Briefly summarize related background research and California case studies to understand what is known and not known, why it is important to develop the proposed conceptual framework, and how California case studies add deeper understanding of regional practices for the water-energy-food nexus and the related ecosystem processes that have climate change implications;

2) Propose a conceptual framework comprised of the major climate change drivers (for changing temperature, snowpack, and precipitation), developing their linkages and pathways for life cycles in water, energy, food, and related ecosystem processes; 
3) Identify knowledge gaps and complexity and discuss challenges and future research needs.

This paper adds missing concept framework and related practices to increase our understanding of how the major climate change drivers of water resources are linked with the increasing energy and food needs for human population growth and what are the related nexus impacts on the ecosystem process that integrated resource management needs to mitigate in order to adopt global climate change at a regional scale. This paper provided research background and developed a road map with concept framework useful for: (1) identifying multiple benefits, managing trade-offs, and building synergies; (2) identifying knowledge gaps for future research; (3) conducting case studies and pilot projects for integrated and cost-effective planning at a regional scale; (4) supporting science-based decision-making for long-term infrastructure investments and using system planning to meet the increasing water, energy, and food needs under climate change pressure without compromised ecosystem function. Furthermore, it provides a starting point that encourages multidisciplinary scientists and researchers using interdisciplinary approaches and comprehensive analyses to assess these complex and nonlinear interactions to add deeper understanding of climate change as a driving force for changing ecosystems services in these interconnected natural resources.

\section{Develop conceptual framework interlinking climate change with water, energy, food, and related ecosystem processes}

Climate change, water, energy, food, and related ecosystem processes are inextricably connected; actions in one area have impacts on the others. Better understanding of these complex and dynamic interrelationships are critical in addressing the increasing demand for fresh water, energy, and food under the pressures of climate change, future population growth, and compromised ecosystem health. Proposed concept framework in this paper includes major climate change drivers of temperature, snowpack, and precipitation with specific pathways and connecting points to interlink energy, water, and food as well as ecosystem processes. Particularly, this conceptual framework focuses on: (1) climate change driving changes in temperature, snowpack, and precipitation and affecting water resources in drought, flood, surface water, ground water, stream flow, water quality, watershed conditions and ecological process and (2) interlinking these climate change driving affects with life cycles in energy and food and related ecosystem processes.

Figure 1 depicts the complex and interlinked structural framework of the major climate change drivers of temperature, snowpack, and precipitation that are

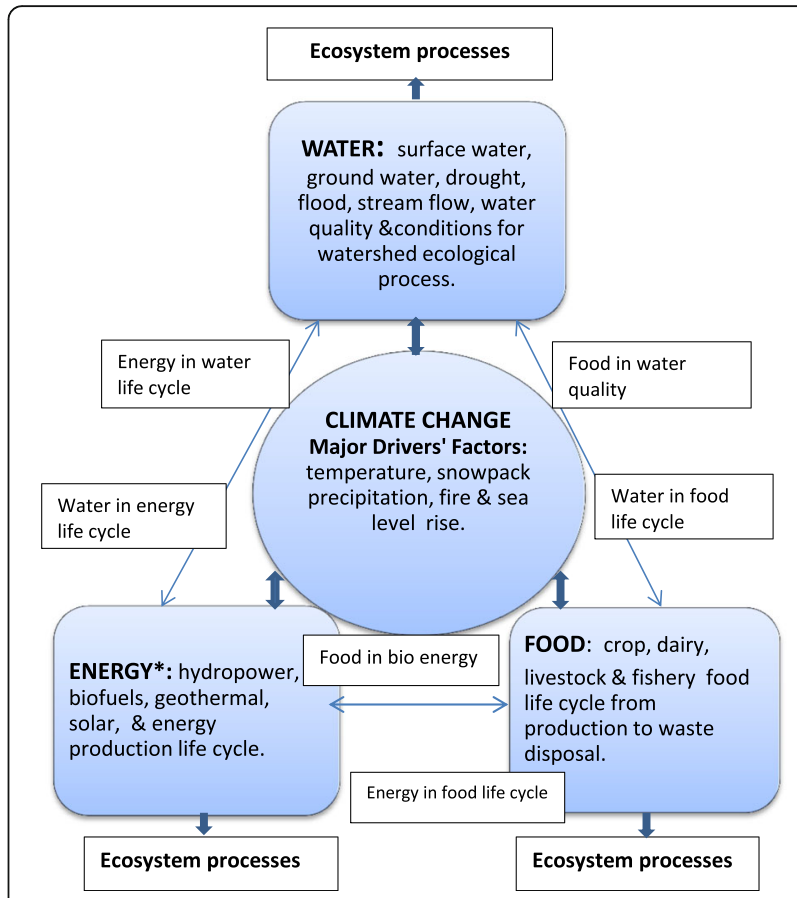

Fig. 1 The proposed conceptual framework. In the conceptual framework, a complex and interrelated structure of the major climate change factors of temperature and snowpack precipitation are interconnected with life cycle pathways of the water, energy, and food nexus as related to ecosystem processes, including forest, wetlands, watershed and stream flow, and water quality for fish and wildlife species. Sea level rise and fire also affects these complex relationships in coastal and forested watershed environments.

Tables 1 and 2 provide the key life cycle pathways and components as well as key points for the interlinkages of this conceptual framework. *Note: Energy includes both renewable and fossil energy from the current practical perspectives in water-energy-food nexus

interconnected with life cycles in water, energy, food, and related ecosystem processes. Climate change driver effects are presented in the center of this conceptual framework as having overall impacts on the life cycles of water, energy, food, and related ecosystem processes, and leading to increased trade-offs and conflicts among these natural resources sectors. Climate change drivers of temperature, snowpack, and precipitation affect the quantity, quality, and timing of water supply and its related uses in life cycles for energy and food production, as well as urban, agricultural, and environmental water benefits. Table 1 highlights the major pathways and components in life cycles of water, energy, food, and ecosystem processes for fish and wildlife in this conceptual framework. Table 2 presents key points for specific interlinkages between these critical elements. Particularly, these inextricable connections and complex relationships include the following: (1) Climate change acts as a major driver of increasing temperature, loss of snowpack, and changing precipitation. Related frequent drought and flooding could significantly reduce water 
Table 1 Key pathways and components in conceptual framework

\begin{tabular}{|c|c|c|}
\hline Components & Key pathways and factors & Notes \\
\hline $\begin{array}{l}\text { Major climate drivers' } \\
\text { factors }\end{array}$ & $\begin{array}{l}\text { Temperature, snowpack, and precipitation for surface water, } \\
\text { ground water, and stream flow. Fire for water quality in watershed; } \\
\text { sea level rise for costal infrastructure }\end{array}$ & $\begin{array}{l}\text { Focused on major drivers' affects in water } \\
\text { resources }\end{array}$ \\
\hline Water life cycle & $\begin{array}{l}\text { Water-pumping, conveyance, distribution and treatment, } \\
\text { and urban and agricultural water use }\end{array}$ & $\begin{array}{l}\text { Conveyance is a part of California water } \\
\text { life cycle }\end{array}$ \\
\hline Energy life cycle & $\begin{array}{l}\text { Cooling, extraction, and processing for energy production, } \\
\text { hydropower, biomass for biofuels, solar, wind, and geothermal } \\
\text { energy production }\end{array}$ & $\begin{array}{l}\text { Fossil energy has negative impacts on } \\
\text { ecosystem processes }^{\mathrm{a}}\end{array}$ \\
\hline Food life cycle & $\begin{array}{l}\text { Irrigation (conveyance, treatment, pumping, pressurizing), harvesting } \\
\text { and processing (cooling, washing, sorting, packaging, heating), fish } \\
\text { and livestock production, transportation (growing and harvesting crops, } \\
\text { shipping, distribution, import and export), food preparation (cooking), } \\
\text { and waste (collecting and processing for food disposal) }\end{array}$ & $\begin{array}{l}\text { Complex process related to water and } \\
\text { energy }\end{array}$ \\
\hline $\begin{array}{l}\text { Affected key components in } \\
\text { ecosystem process }\end{array}$ & $\begin{array}{l}\text { Wetlands and watershed habitats, stream flow, water quality, biodiversity, } \\
\text { cold water fish and wildlife species }\end{array}$ & $\begin{array}{l}\text { Focused on affects from major drivers of } \\
\text { water resources }\end{array}$ \\
\hline
\end{tabular}

${ }^{\mathrm{a}}$ Fossil energy production and use increases greenhouse gas (GHG) emissions and alters ecosystem processes with decreased water quality and increased air pollution

supply and increase water stress, having long-term impacts on the life cycles of water, energy, food, and the beneficial use of water for fish and wildlife; (2) Water is used in the energy life cycle for the generation of hydropower, solar, biofuels, and other energy; energy is used in the water life cycle to extract, convey, treat, distribute, and heat water for urban and agriculture uses; (3) Water is used in the food life cycle for irrigation, harvesting and processing, and fish and livestock production; food production affects water and watershed ecosystems through agricultural runoff containing fertilizers, herbicides, and pesticides, as well as food waste in watersheds; (4) Energy is required to produce, transport, and distribute food; also, crops and biomass are used to produce biofuels; (5) Water, energy, and food production and uses have significant impacts with land and water use and conflicts with ecosystem processes for species and habitats, including forest, wetlands, watershed and stream flow, and water quality for fish and wildlife species. Understanding the complex interrelationships between these elements helps us create integrated resource management strategies to obtain multiple benefits, evaluate trade-offs, and balance different goals and interests to adapt and mitigate for climate change.

As indicated in Table 2, environmental water is critical for healthy fish and wildlife habitats as well as in watershed ecosystem integrity and function. Healthier fish and wildlife habitats in watershed ecosystem processes improve water quality and stabilize water supplies for water, energy, and food. Biodiversity and ecological conditions also affect agricultural food production through biological interactions of plants and insects for crop pollination. Increasing competition for land and water uses between water, energy, food, and environments could have global impacts on ecosystem health and the changing climate. Integrated resource management can be used as a strategy to enhance water, energy, food, and environment security by increasing efficiency and improving coordination across sectors. The proposed conceptual framework is the first step to help us better understand the complex and dynamic interactions between these elements in decision-making processes and allows us to use integrated resource management to adapt and mitigate climate change. California case studies are summarized in the following section to add understanding and address practical issues on how global climate change is interlinked with the water-energyfood nexus as related to ecosystem processes at the regional scale.

\section{Ecosystem service practices and California case studies with climate change implication}

The ecosystem services are attributes of ecological systems that serve people by providing water, energy, food, and healthy environments (Jansson et al. 2000; Barnosky et al. 2013). Ecosystem services have been defined as goods or products, benefits, and natural processes obtained from ecosystems (Millennium Ecocystem Assessment 2005), including the following: (1) regulating the water cycle; (2) providing drinking water and stabilizing water supplies; (3) generating renewable energy; (4) protecting agricultural soils, replenishing their nutrients, and providing food; and (5) helping to protect biodiversity and habitats as well as reduce greenhouse gas (GHG) in the environments. Healthy environments provide ecosystem integrity for ecosystem services security and reduce risks for water, energy, and food supply, including better water quality and biological, physical, and hydrological conditions for water and energy supply and distribution, as well as agricultural food practices. 
Table 2 Key points for interlinkages of climate change, water, energy, and food nexus and related ecosystem processes

\begin{tabular}{|c|c|c|c|c|c|}
\hline Key connections & Climate change (CC) & Water & Energy & Food & Ecosystem process \\
\hline $\begin{array}{l}\text { Climate change } e^{a} \text { in } \\
\text { temperature, snowpack, } \\
\text { precipitation, fire, and sea } \\
\text { level rise }\end{array}$ & Mitigation and adaptation & $\begin{array}{l}\text { Leads to hydrological changes } \\
\text { in surface water and ground } \\
\text { water, increase water stress, } \\
\text { drought and flood, sea water } \\
\text { intrusion, reduce in stream flow } \\
\text { and water quality, affect water } \\
\text { supply and uses }\end{array}$ & $\begin{array}{l}\text { Affects energy production } \\
\text { life cycle (Table 1) and energy } \\
\text { uses by affecting water resources } \\
\text { for energy with increased water } \\
\text { stress }\end{array}$ & $\begin{array}{l}\text { Affects food life cycle (Table 1) } \\
\text { by affecting water supply and } \\
\text { use for food with increased } \\
\text { water stress }\end{array}$ & $\begin{array}{l}\text { Changing ecosystem process by } \\
\text { increasing temperature, fire and } \\
\text { GHG, deceased stream flow, water } \\
\text { quality, increased air pollution with } \\
\text { impacts on forest, biodiversity, land } \\
\text { and watersheds }\end{array}$ \\
\hline Water $^{\mathrm{b}}$ & $\begin{array}{l}\text { Fossil energy use in water life } \\
\text { cycle could increase GHG for } \\
\mathrm{CC} \text { and renewable energy use } \\
\text { in water mitigate CC }\end{array}$ & Integrated water management & $\begin{array}{l}\text { Water affects in energy } \\
\text { production life cycle (Table 1) }\end{array}$ & $\begin{array}{l}\text { Water affects in food life } \\
\text { cycle (Table 1) }\end{array}$ & $\begin{array}{l}\text { Affects environment water for } \\
\text { species habitats in wetland and } \\
\text { watersheds }\end{array}$ \\
\hline Energy $^{c}$ & $\begin{array}{l}\text { Fossil energy generation and } \\
\text { uses increase GHG for CC and } \\
\text { renewable energy mitigates CC }\end{array}$ & $\begin{array}{l}\text { Energy affects in water cycle } \\
\text { (Table 1) }\end{array}$ & Integrated energy management & $\begin{array}{l}\text { Energy affects in food life } \\
\text { cycle (Table 1) }\end{array}$ & $\begin{array}{l}\text { Affects ecosystem processes with } \\
\text { land and habitat conflict from } \\
\text { energy generation and distribution }\end{array}$ \\
\hline Food $^{d}$ & $\begin{array}{l}\text { Fossil energy use for soil, crop, } \\
\text { and other food practices increase } \\
\text { GHG for CC; renewable energy } \\
\text { mitigates CC }\end{array}$ & $\begin{array}{l}\text { Food production and uses as } \\
\text { well as waste could reduce } \\
\text { water quality in watersheds }\end{array}$ & $\begin{array}{l}\text { Food products used in energy } \\
\text { biofuels }\end{array}$ & Integrated food management & $\begin{array}{l}\text { Affects ecosystem process with } \\
\text { land and habitat conflict and } \\
\text { reduces water quality in } \\
\text { watersheds }\end{array}$ \\
\hline Ecosystem process ${ }^{e}$ & $\begin{array}{l}\text { Environmental management for } \\
\text { CC mitigation and adaptation }\end{array}$ & $\begin{array}{l}\text { Increase water quality and } \\
\text { benefits for biological and } \\
\text { hydrological conditions }\end{array}$ & $\begin{array}{l}\text { Interactions of species and } \\
\text { landscape with energy } \\
\text { distribution and production }\end{array}$ & $\begin{array}{l}\text { Interactions of biodiversity, } \\
\text { agricultural lands, and practices }\end{array}$ & $\begin{array}{l}\text { Integrated environmental } \\
\text { management }\end{array}$ \\
\hline
\end{tabular}

${ }^{2}$ Climate change affects temperature, snowpack, precipitation, fire, and sea level rise for water, energy, food, and ecosystem processes

'Water is used (1) for energy production, including cooling and extraction of fossil fuels, hydropower, biofuels, and renewables; (2) for food and biomass production; (3) for drinking and it has multiple beneficial uses, including species and habitats for ecosystem processes

'Energy is used (1) for water production, including water pumping, desalination, conveyance, distribution, and treatment, as well as urban and agricultural water use and (2) for food and biomass production, including energy for water pumping, fertilizers, herbicides, pesticides, food supply chain, food transportation, and processing

${ }^{\mathrm{d}}$ Food crops and biomass are used (1) for energy biofuel production; (2) agricultural food and biomass affects water, including water quality influences resulting from food waste, fertilizers, herbicides, and pesticides from agricultural runoff

${ }^{e}$ Ecosystem process (1) provides ecological function and services for water, energy, food, biomass, and the environment; (2) interconnects natural resources for ecosystem function and process; (3) provides physical, chemical, and biological connections for the environment, including climate and hydrology; environments are physical, chemical, and biological conditions affecting ecosystem processes for water, energy, and food related to climate change 
However, fossil energy use, including natural gas, shale gas, oil, and coal result in GHG emissions and reduce ecosystem services. Limited land resources, inadequate energy supply, and growing water stress bring even more challenges under the pressure of climate change for providing enough water and energy to grow enough food for increasing population demands on these ecosystem services. Climate change could affect the quantity, quality, and timing of ecosystem services, including water uses for power; irrigation for agricultural food production; and water uses for the urban, industrial, and environmental sectors.

Global climate change affects ecosystem processes leading to loss or reduction of sustainable ecosystem services, which could have significant future impacts on water, energy, food, and species and habitats at the regional scales. Reducing energy intensity and fossil energy uses in the water and food sectors can reduce GHG emissions and mitigate climate change. California climate change actions and case studies setup practical examples (Table 3) on how to address these climate change challenges for ecosystem services in the water, energy, food, and environments (California Water Plan 2013, California Department of Water Resources 2015, California Climate Change Research Plan 2015, California Water Action Plan 2014, AB32 Climate Change Scoping Plan 2014, Liu 2016).

California has 10 hydrological regions, each with different types of water supply for their water systems, as indicated in Fig. 2. Water in California is managed at the federal, state, and local levels, managing over 40,000,000 acre-feet of water per year, serving over 30 million people and irrigating nearly 6 million acres of farmland (California Department of Water Resources 2015). Because of California's seasonal and geographical precipitation patterns, large inter-annual precipitation variability and geographical distribution of population, storage, and conveyance of water play a major role in California water management. California Climate Science and data (California Department of Water Resources 2015) indicated that the temperatures in the state have shown a warming trend in the past century, including an increase of 1.1 to $2{ }^{\circ} \mathrm{F}$ in the mean temperature. Major regional climate driver effects include the following: (1) variations for observed temperature increase from 1895 to present and projected temperature increase by mid-twenty-first century; (2) precipitation changes in 33 main water supply watersheds from 1950 to 2012; (3) changes in historical snowpack (1961-1990) and projected (2070-2099) ranges of the snowpack from a lower warming to a higher warming scenario. A trend toward more rain than snow in the total precipitation volume and a decreasing total snowpack could affect one third of the state's water supply. The timing of runoff has changed in California's largest water supply watershed in the Sacramento River system, shifting to earlier in the season. Much of the State's water infrastructure and operation were developed to capture the slow spring runoff from snowpack

Table 3 Examples in related California case studies and practices

\begin{tabular}{|c|c|c|}
\hline Examples & Key points & References \\
\hline Regional climate change affects & $\begin{array}{l}\text { Observed and projected temperature increase, } \\
\text { changes in precipitation, historical, and projected } \\
\text { snowpack; natural climate variability and decadal } \\
\text { scale droughts }\end{array}$ & $\begin{array}{l}\text { California Department of Water } \\
\text { Resources } 2015\end{array}$ \\
\hline Climate Action Plan in State Water Project & $\begin{array}{l}\text { Reduce GHG from SWP operation by terminating } \\
\text { coal-fired power plant, using renewable energy, } \\
\text { and increasing SWP system energy efficiency }\end{array}$ & $\begin{array}{l}\text { California Department of Water } \\
\text { Resources } 2012\end{array}$ \\
\hline Regional water-energy nexus & $\begin{array}{l}\text { A large variation in the average energy intensity } \\
\text { values estimated in the regional water supply }\end{array}$ & $\begin{array}{l}\text { California Water Plan 2013; California } \\
\text { Department of Water Resources } 2015\end{array}$ \\
\hline $\begin{array}{l}\text { Water-energy-food nexus case related } \\
\text { to climate change }\end{array}$ & $\begin{array}{l}\text { WEF nexus cases from California with climate change } \\
\text { implications for energy used in the water life cycle, } \\
\text { qualify energy use and benefits of water and energy } \\
\text { savings related to GHG reduction. Identified multiple } \\
\text { benefits and knowledge gaps in water and energy } \\
\text { used in the food life cycle }\end{array}$ & Liu 2016; Amon et al. 2012 \\
\hline $\begin{array}{l}\text { Hydrology and stressors affects on ecosystem } \\
\text { processes related to climate change }\end{array}$ & $\begin{array}{l}\text { Climate change affecting the Delta and upstream } \\
\text { watershed ecosystems, making the water warmer, } \\
\text { reducing outflows, and restricting Delta smelt and } \\
\text { salmon habitats for endangered species survival } \\
\text { and recovery }\end{array}$ & $\begin{array}{l}\text { Perry et al 2016; Moyle et al. 2016; } \\
\text { Brown et al. 2013, } 2016\end{array}$ \\
\hline $\begin{array}{l}\text { Integrated science and policy cross multiple } \\
\text { sectors }\end{array}$ & $\begin{array}{l}\text { Research and policy for cross sectors' actions in } \\
\text { water, energy, and food as well as environments } \\
\text { related to climate change }\end{array}$ & $\begin{array}{l}\text { California Water Action Plan (2014); } \\
\text { CA Water Plan 2013; California Climate } \\
\text { Change Research (2015), AB32 Climate } \\
\text { Change Scoping Plan 2014 }\end{array}$ \\
\hline
\end{tabular}




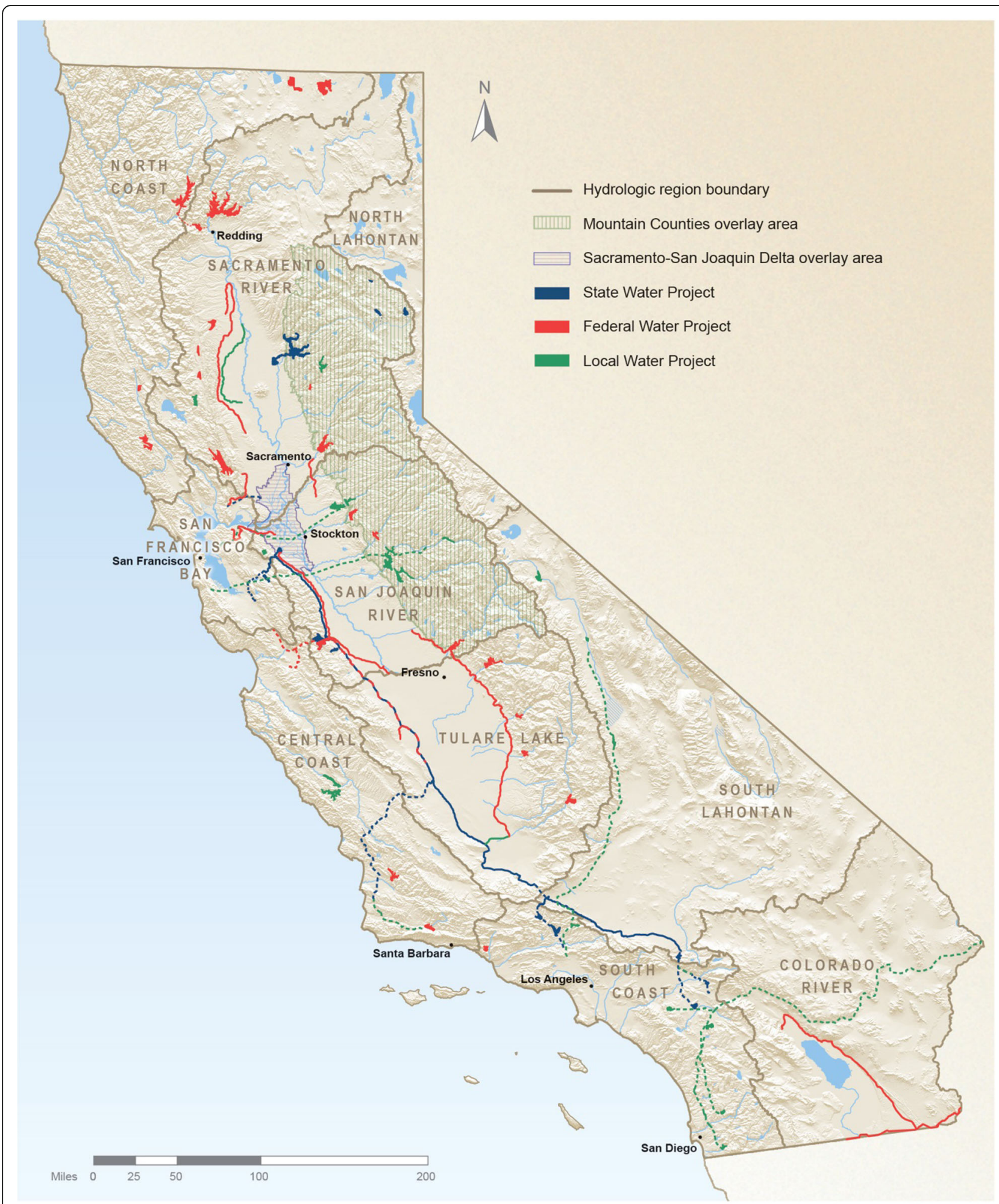

Fig. 2 California hydrological regions and water systems (source: California Climate Science and Data for Water Resources Management, 2015)

and deliver it during the drier summer and fall months. This water infrastructure system, based on historical hydrology, will no longer work in response to these regional climate change affects (California Department of Water Resources 2015). How to address these climate challenges is critical for long-term water infrastructure 
investments and system planning to meet the increasing water needs for energy and food production as related to ecosystem processes.

The California Global Warming Solutions Act of 2006 (Assembly Bill 32 (AB 32)) created a comprehensive multi-year program to reduce GHG emissions for climate change mitigation in California. The AB 32 Scoping Plan and update provides an integrated approach for California to achieve the goal of reducing GHGs emissions with defined targets in 2020 and 2030. Many of the GHG reduction measures have been adopted into California's water, energy, food, and environment sectors. For example, California Water Action Plan (2014) established strategies and a roadmap for water resource reliability, ecosystem restoration and resilience related to these climate change challenges. Resource management strategies (RMS) related to climate change, water, and energy in California include ecosystem restoration, and agriculture and watershed management (CA Water Plan 2013). These RMSs have the goals of reducing water demand, increasing water supply, and improving water quality, environment and resource stewardship, and flood management. Integrated water management approaches are used in these RMS to address climate change issues and ecosystem services related to water, energy, food, and environments.

Greenhouse Gas Emissions Reduction Plan (GGERP) has been adopted as part of the Climate Action Plan in 2012 (California Department of Water Resources 2016). The GGERP plan will cut annual emissions from State Water Project (SWP) operation by more than one million metric tons of GHGs by 2020 and by more than two million metric tons by 2050 . This plan includes reducing GHG releases linked to global warming by $50 \%$ below 1990 levels within the next 7 years by terminating a contract with a coal-fired power plant, joining the Greenergy ${ }^{\circ}$ program, using renewable energy resources, and increasing energy efficiency throughout the SWP system. The plan also sets the stage for an 80 \% GHG emissions reduction by 2050 .

Water and energy relationships with climate change and environmental effects have been studied in the USA and California (Kenney and Wilkinson 2011; CA Water Plan 2013; U.S. Department of Energy 2014; California Department of Water Resources 2015; and Healy et al 2015). Water and energy have a complex relationship with multiple interdependencies, often called the waterenergy nexus. Energy used in water is known as the water's energy intensity, defined as "The total amount of energy required for the use of a given amount of water in a specific location." (CA Water Plan 2013). Only recently has the Climate Change Program at the California Department of Water Resources (DWR) begun to evaluate water and energy related to climate change and bridge energy intensity data gaps for state water supplies in each hydrological region (California Water Plan 2013, California Department of Water Resources 2015). In this regional study, energy intensity was estimated for the extraction and conveyance of water from 10 hydrological regions in California. Regional energy intensity indices were represented by different sizes and numbers of light bulbs for ground water and federal, state, and local water supplies. The study showed there was a large variation in average energy intensity values estimated from ground water and federal, state, and local water supplies both within each hydrological region and among the 10 hydrological regions in California. Adopting this regional study is critical for public decision-making about sustainable water supply choices for agricultural food production, urban consumption, and mitigating climate change.

The larger use of water is in the agriculture section for food production, including $70 \%$ of total global freshwater withdrawals (World Economic Form 2011). Agriculture uses about $40 \%$ of California's available water, compared with $10 \%$ for urban uses; the other $50 \%$ is used as environmental water (Public Policy Institute of California 2015). Climate change is likely to make surface water more scarce, particularly in agricultural food production. Best management practices combined with water and energy use efficiency for agricultural food production can help to reduce fossil energy-related water uses and reduce GHG emission for climate change adaptation and mitigation (Liu 2016). There is limited research in California linking food production to water and energy savings. The water-energy nexus assessment for food process at a Campbell's Soup tomato processing facility in California has identified sustainability opportunities to improve energy and operational efficiency using combined heat and power as well as hot water conservation. Major research finding included related environmental and economic benefits for reduced energy costs, conserved groundwater resources, and reduced GHG emissions and wastewater discharge (Amón et al. 2012). Often, it is difficult to get a clear picture of water and energy used for food systems because the complex food life cycle is broken up categorically, with water, energy, and transportation all being considered separate and unassociated with each other. Lack of research and data for energy intensity in California agricultural crops makes it very difficult to quantify the related water-energy-food nexus at this point (Liu 2016).

California case studies have estimated regional energy intensity and have quantified GHG emissions from the electrical energy used in the water sector for the waterenergy-food nexus that have climate change implications (Liu 2016). The increased regional temperature and water stresses could affect the water and energy nexus 
for agriculture and food production, as well as fish and wildlife habitats. Meanwhile, increasing temperatures will likely boost energy demand for cooling. California case studies have demonstrated increased water and energy use efficiency, increased renewable energy use, and reduced fossil energy use are important factors in offsetting these trends by reducing overall water and energy demand, as well as GHG emissions, for the purpose of climate change adaptation and mitigation. Furthermore, regional decisions and practices are essential in sustainable ecosystem services for efficient water, energy, food systems, and related environmental benefits. These practices can be applicable for other regions in the USA, and other countries, using diversity of regional water resources for energy and food production, with similar climate change challenges.

Climate change with increased temperature, reduced stream flow and water quality, and drought conditions also significantly affect survival and distribution of salmon and cold water fish species and critical habitats in Delta, and San Joaquin and Sacramento watersheds in California. It becomes even more challenging to maintain viable salmon populations with continued drought and ongoing climate change (Perry et al 2016). Climate change effects, including warmer water and reduced outflows as well as changes in precipitation, are already affecting the Delta ecosystems. These changes could significantly affect historic Delta smelt habitat to be uninhabitable by smelt during the summer and early fall (Moyle et al. 2016). Such high temperatures will also restrict distribution of smelt and inhibit their recovery (Brown et al. 2013, 2016). A major consideration in balancing water supply and environmental needs is to prevent the extinction of native species, such as Delta smelt in Bay Delta California, especially during the drought. Delta smelt resiliency strategies and management actions have been developed based on science and conceptual models that address Delta smelt issues and promote their resiliency through the current drought and into future variations of their habitat conditions (California Natural Resources Agency 2016).

Climate change and related droughts create critical challenges in California's integrated water resources management. Paleoclimate records in tree-ring research have been used to document natural hydrologic variability, including extreme events, such as droughts. The decadal scale droughts of the 1920s-1930s and 1980s1990s, particularly in the Sacramento and San Joaquin river basins, remain notably severe in the centuries-tomillennium context (California Department of Water Resources 2015). Significantly less precipitation and warmer temperatures since 2012 have led to statewide drought conditions. This multi-year drought had significant affects on water and energy, the agricultural food industry (California Department of Water Resources 2015; Liu 2016), as well as species and habitats in ecosystem processes (Moyle et al 2016, Perry et al 2016). More than 400,000 acres of farmland were fallowed in response to the drought and other factors. The majority of crop, dairy, and livestock revenue losses resulting from drought occurred in the San Joaquin Valley (California Department of Water Resources, 2016). Drought significantly affected the distribution and abundance of salmon and Delta smelt because of its effects on water quality and habitats in the Delta and upstream watersheds, brought on by record low flows and high water temperatures. Drought reduced the ability of the Delta ecosystems to support Delta smelt by creating warmer water conditions, enabling the rapid invasion of the overbite clam, expansion of Mississippi silverside populations, and the spread of Brazilian waterweed (Moyle et al 2016). Estimated egg-to-fry mortality of naturally spawned winter-run juveniles was $95 \%$ as a result of the increased water temperature during egg incubation through the 2014 drought (Perry et al 2016). Potentially, even greater economic losses and environmental disruption may be incurred at the regional and state levels if the drought continues.

\section{Discussions \\ Complexity and challenges in climate change interlinking with water, energy, and food related to ecosystem processes}

There are enormous challenges in vulnerability and complexity for water, energy, and food related to climate change and ecosystem processes. For example, the Delta is a complex ecosystem that not only supports over 700 species of fish and wildlife but is also used to convey water from Northern California to Southern California, which consumes large amounts of energy. In addition, Delta agricultural land is used for food production. There is a great inherent vulnerability in the complexity of these natural and human-made systems, as well as uncertainty in ecosystem processes. A multitude of stressors threaten our ability to provide a more reliable water supply for energy and food, and protect, restore, and enhance Delta ecosystems. These stressors and related affects in Delta ecosystem services and processes include the following: (1) declining water supply reliability; (2) increasing vulnerability to earthquakes and the associated risk to Delta levees and floods; (3) sinking farmland; and (4) decreasing water quality and increasing invasive species distributions harming native species. These Delta problems could devastate California drinking water and agricultural food production (Service 2007). Many of these stressors produce non-linear affects on the Delta ecosystem processes that do not respond to each stressor individually, since there are 
dynamic interactions of species and habitat quality in such complex ecosystems. In addition, it is uncertain how Delta systems will change in response to both current and future stressors related to changing climate. Complex scopes of interdisciplinary studies are required to understand the major drivers for dynamic interactions and impacts of these stressors on the Delta ecosystem processes. The interdisciplinary research could provide scientific basis for managing ecosystem services in water, energy, and food as related to ecosystem health and climate change. The California Water Action Plan addresses these great challenges for the ecosystem services by establishing objectives of aggressive ecosystem restoration and other steps for environmental benefits (California Water Action Plan 2014).

The studies of the water footprint associated with energy use combined with the future risks of conflicts between electricity production and water availability provided valuable insight on these water use trends in California (Kenney and Wilkinson 2011; Fulton et al. 2012; Fulton and Cooley 2015; Fulton et al. 2014). Increasing water demand and water footprint in application of new technologies and management practices in water, energy, and food sectors presents a great challenge for limited water supplies and water stress related to climate change and ecosystem processes. The treatment and re-use of non-fresh water, as well as the desalination of brackish or saline water, is expected to grow. The desalination process is not only relatively energyintensive but also affects aquatic species and habitats. Using new technology for carbon capture and storage needs both water to strip $\mathrm{CO}_{2}$ from flue gas and power to process concentrated liquefied $\mathrm{CO}_{2}$ (US Department of Energy 2014). Geothermal technology could also use more water to produce renewable energy and affect landscape environments in the ecosystem processes. These complex interactions of water, energy, ecosystems, and climate change should be evaluated, and water and energy efficiency, as well as environmental benefits, should be assessed in the research and development for these new technologies and related management practices at the regional scale.

\section{Identify research needs to evaluate ecosystem services practices with potential multiple benefits and trade-offs}

Ecosystem services practices listed in Table 4 indicate potential multiple benefits and trade-offs as well as conflict in water, energy, and food as related to ecosystem processes for climate change adaptation and mitigation. The examples of these ecosystem services practices include the following: green infrastructure, forest and land management, renewable energy with biomass, best agricultural management practices, and water and energy system efficiency. However, lack of research data and tools for comprehensive analysis limits our deep understanding for benefits and trade-off as well as technical feasibility in these ecosystem service practices. The following section discussed the knowledge gaps and specific research needs related to these practices.

Using green infrastructure that connects water with environments can achieve multiple benefits from the ecosystem services related to climate change (Pitman et al 2015). This living network of green spaces and water systems provides multiple ecosystem services that strengthen the resilience of urban environments, enabling them to mitigate and adapt to climate change, and enhances growth, health, and biodiversity, as well as water, energy, and food security. Riparian vegetation in urban stream watersheds and restored wetlands in the Delta and its upstream ecosystems provide multiple ecosystem services benefits, including modification of temperatures and climatic conditions, carbon sequestration to reduce GHG impact, improved human health and well-being, more effective water management, greater opportunities for biodiversity conservation, and flood protection for food production. For example, DWR has restoration actions for more than 1100 acres of managed wetlands in the Delta. There are over 700,000 acres of diked farmer wetlands in the Delta that are currently private agricultural lands. Conflict and trade-off between wetlands restoration and agricultural land use are the critical issues to be addressed in the Delta green infrastructure practice. How to monitor their effectiveness and assess co-benefits is one of the key research needs identified by (California climate change research plan 2015), including improving methods for modeling ecosystem services and developing a quantitative understanding on the role of wetlands as protective assets for urban areas and other infrastructures to support implementation of multi-benefit restoration projects. Future research models and tools, as well as data systems, should be developed for comprehensive analyses to quantify these cross sector benefits and trade-offs.

Biofuel production is a critical part of renewable energy, which can have considerably larger water footprints. There are land and water use conflicts between biomass for biofuel production with agricultural crops for food production. Climate-affected water scarcity could impact ecosystem services, including producing agricultural food and biofuels and providing healthy wildlife and habitats. One opportunity for California is the production of forest biomass using forest and land management (such as integrated forest operations and thinning). This includes developing forest feed stocks for electricity generation, which can also reduce wildfire danger and improve watershed environments. California Water Plan (2013) recognizes that this approach has multiple land-water benefits, including improving the 
Table 4 Identify multiple benefits, trade-offs, and research needs in ecosystem services practices

\begin{tabular}{|c|c|c|c|c|c|c|}
\hline Ecosystem services practices & $\begin{array}{l}\text { Climate change } \\
\text { adaptation/mitigation }\end{array}$ & Water & Energy & Food & Environments & Research needs \\
\hline $\begin{array}{l}\text { Green infrastructure (e.g., Riparian } \\
\text { vegetation and wetland) }\end{array}$ & Beneficial & $\begin{array}{l}\text { Beneficial and conflict with } \\
\text { water use }\end{array}$ & $\begin{array}{l}\text { Beneficial and trade-off } \\
\text { for energy use }\end{array}$ & $\begin{array}{l}\text { Beneficial or trade-off for } \\
\text { land use }\end{array}$ & Beneficial & $\begin{array}{l}\text { Tools and data to evaluate benefits } \\
\text { and trade-off }\end{array}$ \\
\hline $\begin{array}{l}\text { Forest and land management-(e.g., } \\
\text { integrated forest operations and } \\
\text { thinning.) }\end{array}$ & Beneficial & $\begin{array}{l}\text { Beneficial and conflict with } \\
\text { water use }\end{array}$ & $\begin{array}{l}\text { Beneficial and trade-off for } \\
\text { energy use }\end{array}$ & $\begin{array}{l}\text { Beneficial or trade-off for } \\
\text { land use }\end{array}$ & Beneficial & $\begin{array}{l}\text { Analysis of feasibility cost and } \\
\text { benefits }\end{array}$ \\
\hline Renewable energy with biomass & Beneficial & Trade-off with water use & Beneficial & $\begin{array}{l}\text { Competition and conflict } \\
\text { with land and water }\end{array}$ & Beneficial & $\begin{array}{l}\text { Tools and data for benefits and } \\
\text { conflict }\end{array}$ \\
\hline $\begin{array}{l}\text { Best agricultural management } \\
\text { practices (e.g., carbon sequestration } \\
\text { crop and grassland, drip irrigation, } \\
\text { conservation tillage) }\end{array}$ & Beneficial & Beneficial & $\begin{array}{l}\text { Beneficial or trade-off for } \\
\text { energy use }\end{array}$ & Beneficial & Beneficial & $\begin{array}{l}\text { Tools and data for multiple benefits } \\
\text { and trade-off }\end{array}$ \\
\hline Water and energy system efficiency & Beneficial & Beneficial & Beneficial & Beneficial & Beneficial & Tools and data for multiple benefits \\
\hline
\end{tabular}


water supply reliability, protecting water quality, increasing flood protection, and promoting environmental stewardship (California Department of Water Resources 2012). However, technical feasibility and costs are still the limiting factors for current practical application of this management strategy.

The agricultural sector in California plays an important role in reducing GHG emissions through reduced fossil energy use, modified agricultural practices, and carbon sequestration associated with crop and grassland management. Best agricultural management practices include utilizing renewable resources to reduce nonrenewable inputs of fuel and synthetic nitrogen fertilizer, implementing drip irrigation, conservation tillage, and certified organic production. However, some of these practices, such as drip irrigation, may use more energy to save water as the trade-off (Liu 2016). It is uncertain how farmers may change future practices, what may influence these decisions, and what are the new roles for urban and organic agriculture for future food production. Future research on ecosystem benefits, trade-offs, and cost analyses could provide science-based decision-making to guide these best agricultural management practices.

As discussed earlier, energy intensity is used to evaluate the amount of energy used in the water cycle. The energy intensity of a regional water supply varies greatly depending on water source, conveyance method and efficiency, regional topography, and delivery location. For example, the California South Coast region had relatively high energy intensity from the State Water Project (SWP) supply compared to other regions; the energy intensity from local water projects was relatively low compared to other water supplies in this region. The studies indicated that regional decisions were critical in addressing water-energy conflicts and meeting the local challenges of climate change impacts, including drought (CA Water Plan 2013, California Department of Water Resources 2015). Ecosystem service benefits from water and energy system efficiency include saving water and energy, and a reduced carbon footprint in the California water sector (California Water Plan 2013; Liu 2016). However, future research should be developed for comprehensive analysis of related benefits from reduced water and fossil energy uses for better water quality and increased habitat values in ecosystem processes. The National Water-Economy Database is a coupled system's map of water connecting to food and energy (NWEP 2015). This database and tool could be used to evaluate the water-energy-food nexus and its economic benefits, as well as the aquatic ecosystem impacts for pilot research projects in California.

\section{Identify knowledge gaps as well as future research needs}

It is critical to identify the knowledge gaps in models, data, and tools for integrated assessment. Bridging these gaps is essential in assessing the water-energyfood nexus related to climate change and ecosystem processes. Application of integrated models has been used to quantify the relationships and trade-offs among a comprehensive set of ecosystem service components in the water and energy nexus. For example, California waterenergy modeling platforms are interlinked in order to quantify the water-energy relationships and trade-offs by using the Water Evaluation and Planning (WEAP) and the Long-range Energy Alternatives Planning (LEAP) software (Stockholm Environment Institute 2012). Water and electricity elements are represented and analyzed within the WEAP-LEAP integrated model. Hydropower generation is evaluated by LEAP, while its water availability is simulated in WEAP at the same time. Thermal cooling requirements are based on the electricity demand from LEAP, but the amount of water available is estimated by WEAP. Different interdisciplinary approaches have also been designed to begin assessing the water-energy-food nexus in case studies among 32 Asia-Pacific countries, and integrated tools and physical models, as well as maps and indicators, are used in cost-benefit and efficiency analysis as well as environmental valuation (Taniguchi et al. 2013). In this complex scope of studies, integrated methods from natural science and social science include the following:

1) Integration of environmental governance, science, and co-design/co-production approaches

2) Analysis of both the water-energy and water-food relationships by biophysical measurements, such as space satellite, geothermic and hydrogeological techniques, and geochemical, coastal oceanographic, geophysical, hydrologic, and ecological techniques

3) Social science methodologies using stakeholder analyses, social network analyses, and community surveys by sociology, economics, anthropology, psychology, and behavioral science

However, interdisciplinary research is still lacking with respect to coordinated data collection and integrated model system development, as well as comprehensive analyses for interactions of climate change with ecosystem services in water, energy, food, and related ecosystem processes. This makes it difficult to evaluate and measure their interactions for ecosystem processes and related implications in integrated resource management. The economic values, benefits, and costs of ecosystem services in water and environments are not well defined and quantified due to lack of integrated tools and coordinated data systems as well as integrated public policy. Future interdisciplinary research, including integrated models and data systems, should be developed to: 
1) Measure and analyze complex interactions and linkages of climate change with ecosystem services components and related affects on ecosystem processes.

2) Identify ecosystem services pilot projects, quantify and evaluate costs and benefits as well as trade-offs to support and secure multiple benefits across ecosystem services sectors

The funding, policy, and management support for interdisciplinary research projects could provide science-based management practices to promote efficiency in water, energy, and food production and contribute to ecosystem restoration, GHG reduction, and environmental protection for sustainable ecosystem services.

\section{Conclusions}

In conclusion, there are significant challenges, and interdisciplinary research needs to assess the interactions of climate change with water, energy, and food and related ecosystem processes. Lack of these integrated models and data systems makes it difficult to measure and evaluate these complex interactions and quantify the multiple benefits, costs, and trade-offs between these multiple sectors. The examples and case studies noted here have been used to identify complexity, knowledge gaps, and future research needs to address these significant challenges at the regional scale. It is vital to bridge knowledge gaps and support future research by improving coordinated data collection and developing integrated models and tools as well as integrated data systems. Questions about how to evaluate, quantify, and measure interactions of climate change with water, energy, and food and related ecosystem processes still need further research and discussion among ecologists and multidisciplinary scientists.

The conceptual framework presented in this paper provides the first step toward developing integrated model applications and comprehensive analysis approaches, identifying research pilot projects, and evaluating multiple benefits and the trade-offs across ecosystem service sectors. Future research in this direction could help us to obtain added value and multiple benefits, evaluate a decision in one sector impacting on other sectors, anticipate potential trade-offs and synergies, maximize overall benefits, and minimize risks and impacts on the ecosystem processes. This interdisciplinary research is essential for science-based decision-making and coordinated strategies in integrated resource management for long-term program planning at local, national, and global scales.

\section{Abbreviations}

AB 32: Assembly Bill 32; CA: California; Delta: The Sacramento-San Joaquin Delta; DWR: Department of Water Resources; GGERP: Greenhouse Gas Emissions Reduction Plan; GHG: Greenhouse gas; IPCC: Intergovernmental Panel on Climate Change; LEAP: The Long-range Energy Alternatives Planning; RMS: Resource management strategies; WEAP: The Water Evaluation and Planning

\section{Acknowledgements}

I am thankful for the management support from John Andrew and Elissa Lynn and to all of the reviewers and contributors in the Climate Change Program from the California Department of Water Resources, including Jennifer Morales for her review comments for this paper and other team members' efforts for California climate science and data related to case studies. The editing reviews and comments by Frank Keeley and David $\mathrm{H}$. Schuler and graphic assistances from Scott Olling and Mateo Yanes are also appreciated. A special thank goes to Benjamin $L$ Ruddell for ideas and discussion on the water-energy-food nexus mapping and comprehensive analysis, Sperling J, Gurdak J, and Jablonski LM, as well as others whose inputs and discussions on related topics at meetings and workshops were invaluable.

\section{Author's contributions}

The author contributed significantly to this work. QL designed the overall framework of this paper, conducted a thorough review of the related literature, and developed a review process and summarized case studies, and prepared the conceptual framework and every section of this manuscript.

\section{Author's information}

Qinqin Liu, Ph. D (1990, UC Davis), Senior Environmental Scientist in Climate Change Program, State Integrated Water Management, California Department of Water Resources, California Natural Resources Agency, Sacramento, California, USA. Dr. Liu has 30 years of experience in research and management for biodiversity, natural resource, and ecology as well as climate change, including research managers for Sea Grant and California Interagency Ecology Programs and members on the California Climate Change Action Water-Energy, Forest and Natural Working Lands, and California Climate Change Research Plan Interagency Work Teams.

\section{Competing interests}

The author declares that she has no competing interests.

Received: 16 April 2016 Accepted: 15 September 2016

Published online: 29 September 2016

\section{References}

AB32 Climate Change Scoping Plan (2014) Viewed online at: http://www.arb.ca. gov/cc/scopingplan/2013_update/first_update_climate_change_scoping_ plan.pdf.

Amón R, Wong T, Kazama D, Maulhardt M (2012) Industrial water energy nexus assessment, Campbell Soup California Tomato Processing Facility, University of California Davis.

Barnosky AD, Brown JH, Daily GC, Dirzo R, Ehrlich HA, Ehrlich RP, Eronen TJ, Fortelius M, Hadly AE, Leopold EB, Mooney AH, Myers JP, Naylor LR, Palumbi S, Stenseth NC, Wake HM (2013) Scientific consensus on maintaining humanity's life support systems in the 21st century

Biggs EM, Bruce E, Boruff B, Duncan JMA, Horsley J, Pauli N, McNeill K, Neef A, Ogtrop FV, Curnow J, Haworth B, Duce S, Imanari Y (2015) Sustainable development and the water-energy-food nexus: a perspective on livelihoods. Environ Sci Pol 54:389-397

Brown LR, Bennett WA, Wagner RW, Morgan-King T, Knowles N, Feyrer F, Schoellhamer DH, Stacey MT, Dettinger M (2013) Implications for future survival of Delta smelt from four climate change scenarios for the Sacramento-San Joaquin Delta, California. Estuaries Coasts 36:754-774, doi: http://dx.doi.org/10.1007/s12237-013-9585-4

Brown LR, Komoroske LM, Wagner RW, Morgan-King T, May JT, Connon RE, Fangue NA (2016) Coupled downscaled climate models and ecophysiological metrics forecast habitat compression for an endangered estuarine fish. PLoS ONE 11(1):e0146724, http://dx.doi.org/10.1371/journal. pone.0146724 
California Environmental Protection Agency (2015) Climate Change Research Plan for California. http://climatechange.ca.gov/climate_action_team/reports/CAT_ research_plan_2015.pdf.

California Department of Water Resources (2016 in process) Connecting Dots between Energy, Water, Food, Ecosystems Related to Climate Change for Integrated Water Management in California.

California Department of Water Resources (2012) Climate action plan-phase 1: Greenhouse Gas Emissions Reduction Plan (GGERP)., http://www.water.ca. gov/climatechange/docs/Final-DWR-ClimateActionPlan.pdf

California Department of Water Resources (2015) California climate science and data for water resources management., Viewed online at: http://www.water ca.gov/climatechange/docs/CA_Climate_Science_and_Data_Final_Release_ June_2015.pdf

California Natural Resources Agency (2016) Delta smelt resiliency strategy., http://resources.ca.gov/docs/Delta-Smelt-Resiliency-Strategy-FINAL070816.pdf

California Water Action Plan (2014). Viewed online at: http://resources.ca.gov/ docs/california_water_action_plan/Final_California_Water_Action_Plan.pdf.

California Water Plan Update (2013). Viewed online at: www.waterplan.water.ca. gov/cwpu2013/.

Climate Change Synthesis Report (2014) Contribution of working groups I, II and III to the Fifth Assessment Report of the Intergovernmental Panel on Climate Change [Core Writing Team, Pachauri RK, Meyer LA]. IPCC, Geneva, Switzerland, $151 \mathrm{pp}$.

Fulton J, Cooley H (2015) The water footprint of California's energy system, 1990-2012. Environ Sci Technol 49(6):3314-21.

Fulton J, Cooley H, Gleick PH (2012) California's Water Footprint. Ross N, Luu P (eds) Pacific Institute.

Fulton J, Cooley H, Gleick PH (2014) Water footprint outcomes and policy relevance change with scale considered: evidence from California., Springer Science and Business Media Dordrecht

Godfray HCJ, Crute IR, Haddad L (2010) The future of the global food system. Philos Trans R Soc Lond B Biol Sci 365(1554):2769-2777

Healy RW, Alley WM, Engle MA, McMahon PB, Bales JD (2015) The water-energy nexus - an earth science perspective. USGS Report on Water-Energy Nexus, U.S. Geological Survey Circular 1407, 107 p. Viewed online at: http://dx.doi. org/10.3133/cir1407.

Jablonski LM, Klemow K, Puttick G (2015) Achieving energy and ecological literacies for all: linking ecology and energy education. Perspectives from sessions at Ecological Society of America (ESA) 2014 Annual Meeting. Journal of Sustainability Education. Vol 8. http://www.jsedimensions.org/wordpress/ wp-content/uploads/2015/01/Jablonski-JSE-Vol-8-Jan-2015.pdf.

Jansson NK, Levin S, Lubchenco J, Mäler KG, Simpson D, Starrett D, Tilman D, Walker B (2000) The value of nature and the nature of value. Science 289(5478):395-396

Kenney DS, Wilkinson R (eds) (2011) The water-energy nexus in the American West. Edward Elgar, Northampton, MA

Liu Q (2014) Connecting the dots between energy, water, food, ecosystems and climate change. Ecological Society of America Annual Meeting. Abstract viewed online at: http://eco.confex.com/eco/2014/webprogram/ Paper46698.html

Liu Q (2016) WEF nexus cases from California with climate change implication in: water-energy-food nexus: theories and practices (Salam et al. Eds.), AGU Books, ScholarOne, Wiley-Blackwell (in press).

Millennium Ecosystem Assessment (MA). (2005). Ecosystems and Human WellBeing: Synthesis. Island Press, Washington.

Moyle PB, Brown LR, Durand JR, Hobbs JA (2016) Delta smelt: life history and decline of a once abundant species in the San Francisco Estuary. San Franc Estuary Watershed Sci 14(2). doi: http://dx.doi.org/10.15447/sfews. 2016v14iss2art6

NWEP- National Water-Economy Project. (2015). http://nwep.org/.

Perry RW, Brandes PL, Buchanan RA, Burau JR, Israel JA (2016) Anadromous salmonids in the Delta: new science 2006-2016. San Franc Estuary Watershed Sci 14(2). doi: http://dx.doi.org/10.15447/sfews.2016v14iss2art7

Pitman SD, Daniels CB, Ely ME (2015) Green infrastructure as life support: urban nature and climate change. Trans R Soc S Aust 139:97-112

Public Policy Institute of California (2015) California's water

Rasul G (2014) Food, water, and energy security in South Asia: a nexus perspective from the Hindu Kush Himalayan region. Environ Sci Pol 39:35-48

Service RF (2007) Delta blues, California style. Science 2007:442-445
Skaggs R, Janetos TC, Hibbard KA, Rice SJ (2012) Climate and energy-water-land system interactions, technical report to the U.S. Department of Energy in support of the National Climate Assessment

Stockholm Environment Institute (2012) Software. Accessed at: http://www.sei-us. org/weap.

Taniguchi M, Allen D, Gurdak J (2013) Optimizing the water-energy-food nexus in the Asia-Pacific Ring of Fire, Eos, Transactions of the American Geophysical Union., p 47

The third Assessment of California Climate Change Reports (2012) Accessed at http://www.climatechange.ca.gov/climate_action_team/reports/third_ assessment/index.html

U.S. Department of Energy (2014) The water-energy nexus: challenges and opportunities

Williams JW, Jackson ST, Kutzbach JE (2007) Projected distributions of novel and disappearing climates by 2100 AD. Proc Natl Acad Sci 104:5738-5742

World Economic Forum (WEF) (2011) Water security: the water-food-energyclimate nexus. World Economic Forum, Washington DC. World Resources Institute. 2012. Viewed online at: http://www.wri.org/publication/corporateecosystem-services-review.

\section{Submit your manuscript to a SpringerOpen ${ }^{\circ}$ journal and benefit from:}

- Convenient online submission

- Rigorous peer review

- Immediate publication on acceptance

- Open access: articles freely available online

- High visibility within the field

- Retaining the copyright to your article

Submit your next manuscript at $>$ springeropen.com 